\title{
Influence of Propylparaben on Vitellogenesis and Sex Ratio in Juvenile Zebrafish (Danio rerio)
}

\author{
Přemysl Mikula ${ }^{1}$ Kamila Kružíková1, Radka Dobšíková1, Danka Haruštiaková2, \\ Zdeňka Svobodová ${ }^{1}$ \\ ${ }^{1}$ Department of Veterinary Public Health and Toxicology, University of Veterinary and Pharmaceutical Sciences \\ Brno, Czech Republic \\ ${ }^{2}$ Research Centre for Environmental Chemistry and Ecotoxicology, Masaryk University, Brno, \\ Czech Republic
}

Received September 30, 2008

Accepted December 15, 2008

\begin{abstract}
The aim of the study was to evaluate the xeno-oestrogenic potential of propylparaben in vivo using zebrafish (Danio rerio). Experimental juvenile zebrafish (20 days post hatching) were fed a feed containing 500,1000 , or $2000 \mathrm{mg} \cdot \mathrm{kg}^{-1}$ of propylparaben, fish in a positive control group were given a feed treated with $20 \mathrm{mg} \cdot \mathrm{kg}^{-1}$ of $17 \beta$-oestradiol, and the control fish were given the feed free of either tested substance. The exposure of fish to propylparaben did not affect vitellogenesis after 20 days exposure but seemed to influence the sex differentiation processes, as evidenced by a sex ratio significantly skewed towards females in the group fed $500 \mathrm{mg} \cdot \mathrm{kg}^{-1}$ of propylparaben following 45 days of exposure. The potential of the fish to respond to oestrogenic stimulation was confirmed, since significantly higher vitellogenin concentrations were detected in the fish from the positive control group.
\end{abstract}

Fish, parabens, preservatives, sex differentiation, vitellogenin, xeno-oestrogens

Contamination of the aquatic environment by xenobiotics is presently at the centre of attention in the research community. Hundreds of substances that can adversely affect aquatic organisms can be detected in the aquatic environment. Sewage treatment plant effluents represent a major concern. It has been reported that the exposure of fish to these effluents can decrease plasma testosterone levels and cause feminization of exposed male individuals (Folmar et al. 1996). An increased frequency of the occurrence of intersexual fish has been reported in the aquatic environment not only in Europe (Jobling et al. 1998; Peňáz et al. 2005) but also in North America (Kavanagh et al. 2004). Impaired reproductive capacity as a consequence of reduced gamete production in addition to reduced sperm motility and fertility has been detected in feminised male fish in rivers receiving treated sewage effluents. Female fish from polluted areas have shown a higher incidence of oocyte atresia compared to control females (Jobling et al. 2002ab). Described changes are probably related to the occurrence of (xeno)oestrogenic endocrine disruptors in the aquatic environment.

Endocrine disruptors are chemical substances introduced into the environment that can affect the processes of hormonal regulation in living organisms. In addition to exogenous oestrogens (17 $\beta$-oestradiol, oestrone, oestriol, $17 \alpha$-ethinyloestradiol), xenooestrogens can be also detected in the aquatic environment. These substances can mimic the effects of endogenous oestrogens. The well-known xeno-oestrogens are alkylphenols (i.e. degradation products of alkylphenolethoxylate detergents), bisphenol A, and certain organochlorine insecticides (i.e. DDT and some of its metabolites). Many other substances can be considered suspected xeno-oestrogens based on the results of in vitro experiments demonstrating their ability to bind to oestrogen receptors (ERs).

This is also the case with parabens. Parabens are used as preservatives in the production of drugs, personal care products, and certain foods, since they can act as antibacterial and

Address for correspondence:

Ing. Kamila Kružíková

University of Veterinary and Pharmaceutical Sciences

Palackého 1 - 3, 61242 Brno, Czech Republic
Phone: +420541562783

Fax: +420541562790

E-mail: kruzikovak@vfu.cz

http://www.vfu.cz/acta-vet/actavet.htm 
antifungal agents. The use of more than one paraben in the formulation potentiates their effects. The most commonly used member of this group of chemicals is propylparaben (PP) (Soni et al. 2005).

Vitellogenin is a sensitive biomarker which can be used in the assessment of aquatic environment pollution by (xeno)oestrogens. The synthesis of this glycophosphoprotein in liver of fish is oestrogen-dependent and, under natural conditions, limited to reproductive females. In males and juveniles, any detectable concentration of vitellogenin is negligible, since they have very low levels of endogenous oestrogens. However, the exposure of male or juvenile fish to exogenous oestrogens or xeno-oestrogens may induce the production of vitellogenin in these individuals (Denslow et al. 1999).

In addition to the influence of (xeno)oestrogens on vitellogenin production, these substances have also demonstrated the ability to affect the gonad development process. In addition to genetic factors, the differentiation of fish gonads depends on both environmental (water temperature, photoperiod, illumination level) and social (density of fish population, hierarchy, aggression) factors (Baroiller et al. 1999; Strussman and Nakamura 2002). It has been reported that the exposure of juvenile fish to (xeno)oestrogens during the critical period of gonad development can induce a shift in the sex ratio of exposed fish population. Varying levels of predominance of females, depending on the species and exposure dose and duration, have been observed in fish populations exposed to (xeno)oestrogens (Örn et al. 2003, 2006; Drastichová et al. 2005).

Due to its small size, the ease of reproduction and rearing, and short generation interval, zebrafish (Danio rerio) is one of the most commonly used fish species in (xeno)oestrogenic potential testing. Zebrafish pass through a stage of juvenile hermaphroditism (protogyny) during gonad development. Takahashi (1977) established that in all zebrafish, irrespective of sex, premature ovaries are formed at the beginning of the differentiation period. These gonads, which are not fully differentiated or functional, are detectable 20 days post hatching (dph). Subsequently, protogynic ovaries in approximately half of the fish are transformed to testes. Oocyte apoptosis of premature ovaries, controlled by endogenous sex hormones, is probably the trigger factor for this transition (Uchida et al. 2002). Some authors have considered the gonad differentiation to be completed at the age of 30 to 40 dph (Takahashi 1977; Uchida et al. 2002). Others have reported fully developed male and female gonads in zebrafish to be visible at approximately 60 days (Andersen et al. 2004). Maack and Segner (2004) distinguished 3 separate periods of gonad development in the zebrafish. They identified the period 15 to 42 days post fertilization (dpf) as the juvenile hermaphroditic stage. This period is followed by the gonad transition stage (43 to $71 \mathrm{dpf}$ ) and, subsequently, by the premature stage of testicular and ovarian development (72 to $99 \mathrm{dpf}$ ). After the third developmental period all zebrafish should be considered mature (Maack and Segner 2004).

The aim of this study was to evaluate the xeno-oestrogenic potential of propylparaben in vivo using juvenile zebrafish as a test species.

\section{Experimental design}

\section{Materials and Methods}

Following a 3 day adaptation period, 350 juvenile zebrafish (20 days post hatching) were divided into ten 15 1 glass tanks ( 2 control tanks, 2 tanks for each propylparaben (PP) exposure regime), and 2 tanks for positive controls exposed to natural oestrogen $17 \beta$-oestradiol (E-2). There were 35 juvenile zebrafish in each tank. Tanks contained 101 of water prepared according to ISO 7346-2. The $\mathrm{pH}$ value of water during the test was $7.7 \pm 0.2$, oxygen saturation ranged from 61.0 to $72.6 \%$ and tank water temperature was $24.5 \pm 1.5^{\circ} \mathrm{C}$. The photoperiod was $12: 12 \mathrm{~h}$ (light : dark). During the test, fish were fed three times a day with a food containing either PP, E-2, or no added substance (see below). Three times per week the tank bath was renewed.

Feed preparation

Appropriate amounts of PP and E-2 were diluted in ethanol (96\%). Prepared solutions were mixed with decapsulated brine shrimp (Artemia salina) eggs, and the solvent was evaporated by dry warm air $\left(40^{\circ} \mathrm{C}\right)$. Five 
batches of feed were prepared. The feed for experimental fish contained 500, 1000, or $2000 \mathrm{mg} \cdot \mathrm{kg}^{-1} \mathrm{PP}$. Fish in the positive control group were fed with feed containing $20 \mathrm{mg} \cdot \mathrm{kg}^{-1} \mathrm{E}-2$. Feed for the control group was treated with the solvent only.

Vitellogenin ELISA assay

The measurement of vitellogenin concentrations in whole-body homogenates was performed using the Zebrafish vitellogenin ELISA kit (Biosense AS, Bergen, Norway).

After 20 days of exposure, six randomly selected fish from each tank were killed by placing in a tank filled with carbon dioxide saturated water. Lengths and weights were immediately recorded and fish were transferred to a deep-freeze box $\left(-85^{\circ} \mathrm{C}\right)$, where they were stored for ca 30 days. Then the stored fish were defrosted on ice. Homogenizing buffer ( $\mathrm{pH} 8.0$ ), containing $50 \mathrm{mM}$ tris- $\mathrm{HCl}, 0.02 \%$ aprotinin and $0.1 \mathrm{mM}$ phenylmethane sulphonylfluoride, was added to fish in micro test tubes at a $2: 1$ volume-to-weight ratio. The fish were homogenized and then centrifuged for $1 \mathrm{~h}$ at $4{ }^{\circ} \mathrm{C}$ at about $14000 \mathrm{~g}$. Dilutions of vitellogenin standards and of sample supernatants were made. Because of poor vitellogenin stability, all standards and samples were cooled with ice when handled. Specific anti-vitellogenin antibody was placed in the wells of microtitration plates, and diluted standards and samples were transferred onto them. Primary antibodies, secondary antibodies conjugated with horseradish peroxidase enzyme, and substrate were gradually applied. Microtitration plate wells were washed with buffer between steps. Absorbance at wavelength $\lambda=492 \mathrm{~nm}$ was measured using Multiscan RC (Labsystems, Helsinki, Finland). Absorbance values of standards were plotted as calibration curves, which were then used to determine vitellogenin concentrations in homogenates of individual fish.

Determination of sex ratio

After 45 days of exposure all fish that remained in tanks were killed in carbon dioxide saturated water, and weight and length was recorded. Fish were fixed in $10 \%$ formalin and embedded into paraffin blocks. Longitudinal sections $(5 \mu \mathrm{m})$ were cut and stained with haematoxylin-eosin. The sex of each fish was determined using light microscopy.

\section{Statistical analysis}

The Kruskal-Wallis non-parametric test was used to compare differences in vitellogenin concentrations among fish groups. When significant differences were found, multiple comparisons were then performed to identify pairs of groups with significant differences. The hypothesis was tested at significance level $\alpha=0.05$.

Fisher's exact test was used to analyse the difference in sex ratio between control group and groups exposed to $\mathrm{PP}$ in different concentrations (500 mg. kg-1, $\left.1000 \mathrm{mg} \cdot \mathrm{kg}^{-1}, 2000 \mathrm{mg} \cdot \mathrm{kg}^{-1}\right)$. Considering multiple use of Fisher's exact test, this hypothesis was tested at adjusted significance level $\alpha=0.017(0.05 / 3$; Bonferroni correction). Data analyses were performed using Statistica software (StatSoft Inc. 2007).

\section{Results}

The mean length and weight of fish from the control group at 20 days were $17.2 \mathrm{~mm}$ and $83.1 \mathrm{mg}$, respectively. These values did not differ significantly from those of other groups. At the end of exposure (45 days), no significant differences were found between lengths and weights of fish in groups exposed to PP and those of the control group. Mean length and weight of control fish were $25.3 \mathrm{~mm}$ and $277.9 \mathrm{mg}$. However, mean values of these variables in the group of fish exposed to E-2 were significantly lower, i.e. length, $20.0 \mathrm{~mm}$ and weight, $180.8 \mathrm{mg}$.

The results of vitellogenin measurements are summarized in Table 1 and Fig. 1. Significantly higher concentrations of vitellogenin in whole-body homogenates of fish exposed to E-2 were detected in comparison to all other groups (Kruskal-Wallis test: $\mathrm{Q}=28.68 ; \mathrm{N}=60 ; P$

Table 1. Vitellogenin concentrations $\left[\mathrm{ng} \cdot \mathrm{ml}^{-1}\right]$ in whole-body homogenates of juvenile zebrafish exposed to propylparaben (PP) or $17 \beta$-oestradiol (E-2) $\left[\mathrm{ng} \cdot \mathrm{ml}^{-1}\right]$

\begin{tabular}{|l|c|c|c|}
\hline Treatment & $\mathrm{N}$ & Median & Range \\
\hline control group & 12 & $854^{\mathrm{a}}$ & $(454-2265)$ \\
\hline PP $500 \mathrm{mg} \cdot \mathrm{kg}^{-1}$ & 12 & $799^{\mathrm{a}}$ & $(551-4590)$ \\
\hline PP $1000 \mathrm{mg} \cdot \mathrm{kg}^{-1}$ & 12 & $830^{\mathrm{a}}$ & $(553-1720)$ \\
\hline PP $2000 \mathrm{mg} \cdot \mathrm{kg}^{-1}$ & 12 & $811^{\mathrm{a}}$ & $(399-3588)$ \\
\hline E-2 $20 \mathrm{mg} \cdot \mathrm{kg}^{-1}$ & 12 & $1177946^{\mathrm{b}}$ & $(872654-1510100)$ \\
\hline
\end{tabular}

Groups with different alphabetical superscripts differ significantly at $P<0.05$. (Kruskal-Wallis test followed by multiple comparisons).
$<0.001$; multiple comparison: differences between E-2 and all other groups $P<0.001$; Table 1 ). Because of significantly different vitellogenin concentrations in the group exposed to E-2, this group was omitted from subsequent analyses. Significant differences among remaining groups were not found (Kruskal-Wallis test: $\mathrm{Q}=0.55, \mathrm{~N}=48 ; P=0.909$; Fig. 1). 


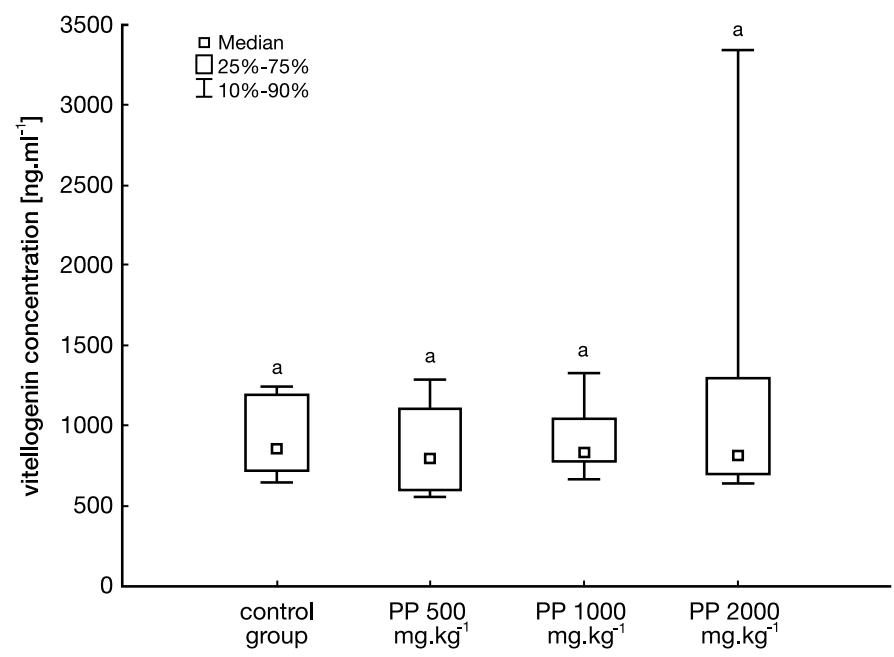

Fig 1. Vitellogenin concentrations in whole-body homogenates of juvenile zebrafish (Danio rerio) $\left[\mathrm{ng} \cdot \mathrm{ml}^{-1}\right]$. The group exposed to $17 \beta$-oestradiol (E-2) was not included in analysis.

Table 2. Sex ratio in groups of juvenile zebrafish (Danio rerio) exposed to propylparaben (PP) and $17 \beta$-oestradiol (E-2)

\begin{tabular}{|l|c|c|c|c|c|c|c|}
\hline Treatment & $\mathrm{N}$ & Females (F) & Males (M) & Not determined & Detection [\%] & $\begin{array}{c}\mathrm{F}(\% \text { from } \\
\text { determined })\end{array}$ & $\begin{array}{c}\mathrm{M}(\% \text { from } \\
\text { determined })\end{array}$ \\
\hline control group & $56 / 2$ & 22 & 33 & 1 & 98.2 & 40.0 & 60.0 \\
\hline PP $500 \mathrm{mg} \cdot \mathrm{g}^{-1}$ & $57 / 1$ & 39 & 16 & 2 & 96.5 & 70.9 & 29.1 \\
\hline PP $1000 \mathrm{mg} \cdot \mathrm{kg}^{-1}$ & $53 / 5$ & 32 & 21 & 0 & 100.0 & 60.4 & 39.6 \\
\hline PP 2000 $\mathrm{mg} \cdot \mathrm{kg}^{-1}$ & $56 / 2$ & 32 & 21 & 3 & 94.6 & 60.4 & 39.6 \\
\hline E-2 20 $\mathrm{mg} \cdot \mathrm{kg}^{-1}$ & $34 / 24$ & 0 & 0 & 34 & 0.0 & - & - \\
\hline
\end{tabular}

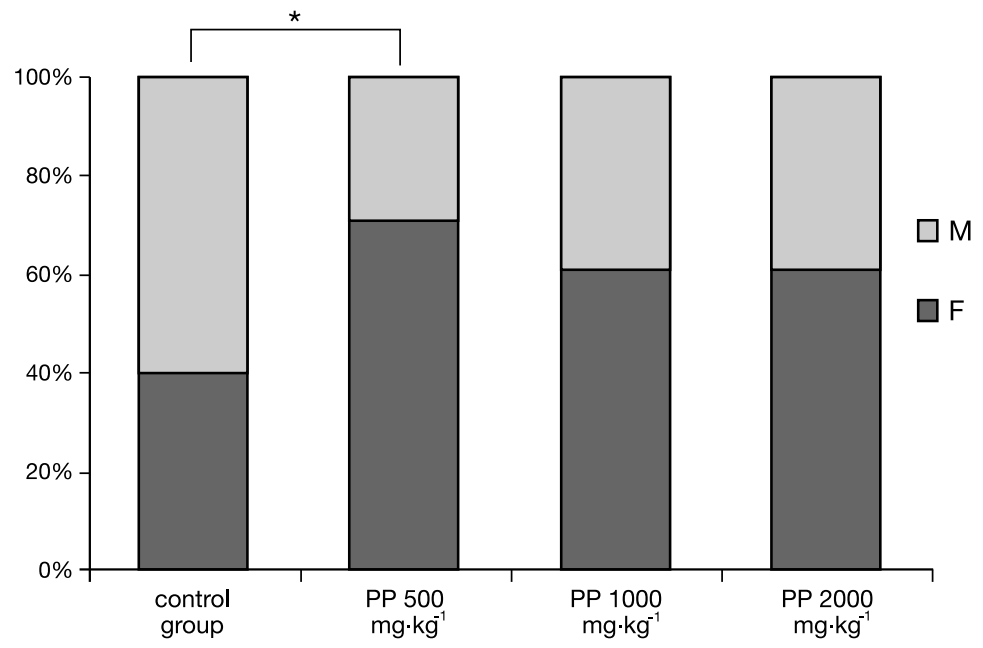

Fig 2. Sex ratio in control group and groups exposed to PP. Groups marked with asterisk differ significantly at $P$ $<0.017(\mathrm{M}=$ male, $\mathrm{F}=$ female $)$. 
The results of sex determination are reported in Table 2 and in Fig. 2. It was found that the exposure dose of $17 \beta$-oestradiol used in our experiment (i.e. $20 \mathrm{mg} \cdot \mathrm{kg}^{-1}$ ) was excessive and resulted in mortality, despite the fact that it was chosen in accordance with the previous study of Drastichová et al. (2005). After 25 days, the first clinical signs of E-2 poisoning were observed in exposed fish. The skin became markedly light coloured, and petechial haemorrhages occurred on the skin and fins of some fish. Progressive cardiac hypertrophy was also visible in fish exposed to E-2. At the end of the exposure, mortality of fish from the positive control group was $41.4 \%$, while, in the remaining four groups, mortality was negligible (1.7-8.6\%). The occurrence of well developed urogenital papillae was recorded in all fish from the positive control group. However, the sex of fish from the positive control group could not be determined, since no visible gonads were observed, hence this group was omitted from the statistical analysis of fish sex ratio. This analysis confirmed significantly skewed sex ratio towards females in the group of fish fed with the feed containing $500 \mathrm{mg} \cdot \mathrm{kg}^{-1}$ of PP compared to control (Fisher's exact test: $P=0.002$ ). The shift in sex ratio was observed also in other groups taking PP-treated feed, but the differences were not significant (in all other comparisons Fisher's exact test: $P>0.017$ ).

\section{Discussion}

The xeno-oestrogenic potential of parabens has been described in some in vitro studies (Routledge et al. 1998; Okubo et al. 2001; Byford et al. 2002). In in vivo studies dealing with the monitoring of xeno-oestrogenic effects of parabens, the results differ markedly. The induction of vitellogenesis (i.e. oestrogenic response) was reported following intraperitoneal administration of ethyl-, propyl-, and buthylparaben to juvenile rainbow trout (Oncorhynchus mykiss) (Pedersen et al. 2000). Exposure of this fish species to PP added to the water or administered in feed has also resulted in higher vitellogenin concentrations in exposed fish compared to controls (Bjerregaard et al. 2003). Similarly, levels of plasma vitellogenin increased in a dose-dependent manner in the medaka (Oryzias latipes) exposed to PP added to the water (Inui et al. 2003). On the other hand, results of our previous study suggested that, in juvenile zebrafish, water-borne exposure to propylparaben can induce an anti-oestrogenic effect (Mikula et al. 2006).

In the present study, the exposure of fish to three different concentrations of PP administered in food did not cause either significant induction or inhibition of vitellogenin synthesis. Neither oestrogenic nor anti-oestrogenic effect was observed in PP exposed fish. The potential of the fish used in our experiment to respond to oestrogenic stimulation was confirmed, since, in fish from the positive control group exposed to E-2, significantly higher vitellogenin concentration was detected compared to the control as well as to all PP-treated groups.

Gonad differentiation processes are labile in teleosts. The phenotypic sex of teleosts is coded genetically and may be influenced by non-genetic factors. No sex chromosomes have been discovered in zebrafish, thus an important role of non-genetic factors on the processes of sex differentiation is expected. Social and environmental factors participate in these processes (Baroiller et al. 1999; Strussman and Nakamura 2002). Shang et al. (2006) reported that hypoxia can affect sex differentiation and sex development of zebrafish, leading to a male-biased population in F1 generation. Rearing in warm water (i.e. 35 and $37^{\circ} \mathrm{C}$ ) at $15-25$ days post hatching was shown to increase gonadal masculinisation of genetic all-female zebrafish (Uchida et al. 2004). Sex differentiation is also influenced by sex steroids and sex hormone mimicking or antagonizing substances. Changes in the proportions of males and females were observed in populations of juvenile zebrafish exposed, during the critical period of gonadal development, to $17 \alpha$-ethinyloestradiol and methyltestosterone (Örn et al. 2003), trenbolone (Örn et al. 2006), anti-oestrogen ZM 189, 156 (Andersen et al. 2004), the fungicide prochloraz (Kinnberg et al. 2007), and 
bisphenol A (Drastichová et al. 2005). Recently, effects of the thyroid hormone inhibitor perchlorate on the sex ratio were also studied. While the juvenile-larval exposure of zebrafish skewed the phenotypic sex ratio towards females (whereas co-treatment of fish with exogenous thyroxine skewed it towards males), Mukhi et al. (2007), Bernhardt et al. (2006) reported masculinisation of female three-spined stickleback (Gastrosteus aculeatus) exposed to the same substance.

According to genetic rules, the sex ratio near 1:1 should be expected in the control group, however, sex ratios reported by authors differ markedly. While certain authors observed a dominance of male zebrafish in control groups of their experiments (e.g. $69 \%$ and $58 \%$, Brion et al. 2004, or 68\%, Andersen et al. 2001), other authors reported a balanced (i.e. approximately $1: 1$ ) sex ratio (Maack and Segner 2004; Drastichová et al. 2005). Örn et al. $(2003,2006)$ determined control groups of their experiment using zebrafish to be $67 \%$ female, and similar results were described by Andersen et al. (2004), who reported 72\% females in their control group.

In our experiment, the control group was determined to comprise $60 \%$ male individuals and $40 \%$ females. A shift in the sex ratio was observed in all experimental groups exposed to PP, however, a significant difference compared to the control was detected only in the group exposed to $500 \mathrm{mg} \cdot \mathrm{kg}^{-1}$, where $71 \%$ of the fish were female. Unfortunately, in the positive control group the sex ratio could not be determined, since the exposure dose of E-2 was excessively high. The impossibility of sex determination of E-2 exposed fish supports the statement of Mills et al. (2001), who reported gonadal regression in male summer flounder as a consequence of E-2 exposure. Indeed, in our experiment, gonads of fish exposed to E-2 either did not develop or had regressed prior to the end of the experiment when fish were sampled. However, occurrence of well developed urogenital papillae in fish exposed to E-2 confirmed their estrogenic exposure as was previously reported by Brion et al. (2004). Histological examination of fish surviving the entire period of E-2 exposure showed a similar histological picture to that previously described by Zaroogian et al. (2001) in juvenile male summer flounder (Paralichthys dentatus) following injection of E-2.

In conclusion, the results of our study are surprising. Two endpoints to assess the xenooestrogenic potential of propylparaben were used (i.e. vitellogenin concentrations in wholebody homogenates of fish after 20 days exposure and the sex ratio in groups of fish following 45 days exposure). Despite the fact that the exposure did not significantly affect the vitellogenin synthesis in exposed fish, with neither xeno-oestrogenic nor anti-oestrogenic effect observed, the results of histological determination of fish sex suggested the ability of the substance tested to influence the process of gonad development. Participation of environmental factors on this effect may be ruled out, since the temperature and lightning regimes were the same in all tanks and oxygen saturation did not differ significantly among the tanks. Sex differentiation in zebrafish is poly-factorial and can be influenced by certain hormones or endocrine disruptors. Based on the results of our study we can say that the effect of propylparaben on the sex differentiation of zebrafish seems not to be mediated by the oestrogen receptor (ER), since vitellogenin concentrations were not affected in exposed fish. The skewed sex ratio in the groups of fish may be explained by the interference of hypothalamo-pituitary-gonadal (HPG) axis or of other hormones influencing sex differentiation processes, such as thyroid hormones. These findings should be used in further research dealing with the issue of possible adverse effects of parabens on endocrine disruption in vertebrates.

\section{Vliv propylparabenu na vitellogenezi a poměr pohlaví u juvenilního dania pruhovaného (Danio rerio)}

Cílem této práce bylo zhodnotit xeno-estrogenní potenciál propylparabenu in vivo na testovacím organismu daniu pruhovaném (Danio rerio). Juvenilní stádia dania pruhovaného 
(20 dní po vykulení plůdku) byla krmena krmivem s obsahem propylparabenu 500, 1000 nebo $2000 \mathrm{mg} \cdot \mathrm{kg}^{-1}$, v pozitivní kontrolní skupině byl do krmiva přidán $17 \beta$-estradiol v koncentraci $20 \mathrm{mg} \cdot \mathrm{kg}^{-1}$ a v kontrolní skupině bylo použito krmivo bez těchto látek. Po dvacetidenní expozici propylparabenu nebyl zjištěn efekt na vitellogenezi, avšak zdá se, že expozice měla vliv na proces pohlavní diferenciace (ve skupině exponované $500 \mathrm{mg}$ propylparabenu na kg krmiva byl po 45 dnech expozice zjištěn výrazný posun poměru pohlaví ve prospěch samic). Vzhledem k významně vyšší koncentraci vitellogeninu v pozitivní kontrole byla potvrzena reakce ryb na estrogenní stimulaci.

\section{Acknowledgements}

This study was a part of a long-term research project MSM 6215712402.

\section{References}

Andersen L, Petersen G, Gessbo A, Örn S, Holbech H, Bjerregaard P, Norrgren L 2001: Zebrafish Danio rerio and roach Rutilus rutilus: Two species suitable for evaluating effects of endocrine disrupting chemicals? Aquat Ecosyst Health Manag 4: 275-282

Andersen L, Kinnberg K, Holbech H, Korsgaard B, Bjerregaard P 2004: Evaluation of a 40 day assay for testing endocrine disrupters: Effects of an anti-estrogen and an aromatase inhibitor on sex ratio and vitellogenin concentrations in juvenile zebrafish (Danio rerio). Fish Physiol Biochem 30: 257-266

Baroiller JF, Guiguen Y, Fostier A 1999: Endocrine and environmental aspects of sex differentiation in fish. Cell Mol Life Sci 55: 910-931

Bernhardt RR, Von Hippel FA, Cresko WA 2006: Perchlorate induces hermaphroditism in threespine sticklebacks. Environ Toxicol Chem 25: 2087-2096

Bjerregaard P, Andersen DN, Pedersen KL, Pedersen SN, Korsgaard B 2003: Estrogenic effect of propylparaben (propylhydroxybenzoate) in rainbow trout Oncorhynchus mykiss after exposure via food and water. Comp Biochem Physiol C-Toxicol Pharmacol 136: 309-317

Brion F, Tyler CR, Palazzi X, Laillet B, Porcher JM, Garric J, Flammarion P 2004: Impacts of 17 $\beta$-estradiol, including environmentally relevant concentrations, on reproduction after exposure during embryo-larval-, juvenile- and adult-life stages in zebrafish (Danio rerio). Aquat Toxicol 68: 193-217

Byford JR, Shaw LE, Drew MGB, Pope GS, Sauer MJ, Darbre PD 2002: Oestrogenic activity of parabens in MCF7 human breast cancer cells. J Steroid Biochem Mol Biol 80: 49-60

Denslow ND, Chow MC, Kroll KJ, Green L 1999: Vitellogenin as a biomarker of exposure for estrogen or estrogen mimics. Ecotoxicology 8: 385-98

Drastichová J, Svobodová Z, Groenland M, Dobšíková R, Žlábek V, Weissová D, Szotkowská M 2005: Effect of exposure to bisphenol A and 17ß-estradiol on the sex differentiation in zebrafish (Danio rerio). Acta Vet Brno 74: $287-291$

Folmar LC, Denslow ND, Rao V, Chow M, Crain DA, Enblom J, Marcino J, Guillette LJ Jr 1996: Vitellogenin induction and reduced serum testosterone concentrations in feral male carp (Cyprinus carpio) captured near a major metropolitan sewage treatment plant. Environ Health Perspect 104: 1096-1101

Inui M, Adachi T, Takenaka S, Inui H, Nakazawa M, Ueda M, Watanabe H, Mori C, Iguchi T, Miyatake K 2003: Effect of UV screens and preservatives on vitellogenin and choriogenin production in male medaka (Oryzias latipes). Toxicology 194: 43-50

Jobling S, Beresford N, Nolan M, Rodgers-Gray T, Brighty GC, Sumpter JP, Tyler CR 2002a: Altered sexual maturation and gamete production in wild roach (Rutilus rutilus) living in rivers that receive treated sewage effluents. Biol Reprod 66: 272-281

Jobling S, Coey S, Whitmore JG, Kime DE, Van Look KJW, McAllister BG, Beresford N, Henshaw AC, Brighty G, Tyler CR, Sumpter JP 2002b: Wild intersex roach (Rutilus rutilus) have reduced fertility. Biol Reprod 67: 515-524

Jobling S, Nolan M, Tyler CR, Brighty G, Sumpter JP 1998: Widespread sexual disruption in wild fish. Environ Sci Technol 32: 2498-2506

Kavanagh RJ, Balch GC, Kiparissis Y, Niimi AJ, Sherry J, Tinson C, Metcalfe CD 2004: Endocrine disruption and altered gonadal development in white perch (Morone americana) from the lower Great Lakes region. Environ Health Perspect 112: 898-902

Kinnberg K, Holbech H, Petersen GI, Bjerregaard P 2007: Effects of the fungicide prochloraz on the sexual development of zebrafish (Danio rerio). Comp Biochem Physiol C-Toxicol Pharmacol 145: 165-170

Maack G, Segner H 2004: Life-stage-dependent sensitivity of zebrafish (Danio rerio) to estrogen exposure. Comp Biochem Physiol C-Toxicol Pharmacol 139: 47-55

Mikula P, Dobšíková R, Svobodová Z, Jarkovský J 2006: Evaluation of xenoestrogenic potential of propylparaben in zebrafish (Danio rerio). Neuroendocrinol Lett 27: 104-107

Mills LJ, Gutjahr-Gobell RE, Haebler RA, Horowitz DJB, Jayaraman S, Pruell RJ, McKinney RA, Gardner GR, 
Zaroogian GE 2001: Effects of estrogenic (o,p'-DDT; octylphenol) and anti-androgenic (p,p'-DDE) chemicals on indicators of endocrine status in juvenile male summer flounder (Paralichthys dentatus). Aquat Toxicol 52: 157-176

Mukhi S, Torres L, Patino R 2007: Effects of larval-juvenile treatment with perchlorate and co-treatment with thyroxine on zebrafish sex ratios. Gen Comp Endocrinol 150: 486-494

Okubo T, Yokoyama Y, Kano K, Kano I 2001: ER-dependent estrogenic activity of parabens assessed by proliferation of human breast cancer MCF-7 cells and expression of ER $\alpha$ and PR. Food Chem Toxicol 39: $1225-1232$

Örn S, Holbech H, Madsen TH, Norrgren L, Petersen GI 2003: Gonad development and vitellogenin production in zebrafish (Danio rerio) exposed to ethinylestradiol and methyltestosterone. Aquat Toxicol 65: 397-411

Örn S, Yamani S, Norrgren L 2006: Comparison of vitellogenin induction, sex ratio, and gonad morphology between zebrafish and Japanese medaka after exposure to $17 \alpha$-ethinylestradiol and $17 \beta$-trenbolone. Arch Environ Contam Toxicol 51: 237-243

Pedersen KL, Pedersen SN, Christiansen LB, Korsgaard B, Bjerregaard P 2000: The preservatives ethyl-, propyland butylparaben are oestrogenic in an in vivo fish assay. Pharmacol Toxicol 86: 110-113

Peňáz M, Svobodová Z, Baruš V, Prokeš M, Drastichová J 2005: Endocrine disruption in a barbel, Barbus barbus population from the River Jihlava, Czech Republic. J Appl Ichtyol 21: 420-428

Routledge EJ, Parker J, Odum J, Ashby J, Sumpter JP 1998: Some alkyl hydroxy benzoate preservatives are weakly estrogenic. Toxicol Appl Pharmacol 153: 12-19

Shang EHH, Yu RMK, Wu RSS 2006: Hypoxia affects sex differentiation and development, leading to a maledominated population in zebrafish (Danio rerio). Environ Sci Technol 40: 3118-3122

Soni MG, Carabin IG, Burdock GA 2005: Safety assessment of esters of p-hydroxybenzoic acid (parabens). Food Chem Toxicol 43: 985-1015

STATSOFT INC. 2007: STATISTICA (data analysis software system), version 8.0. www.statsoft.com.

Strussmann CA, Nakamura M 2002: Morphology, endocrinology, and environmental modulation of gonadal sex differentiation in teleost fishes. Fish Physiol Biochem 26: 13-29

Takahashi H 1977: Juvenile hermaphroditism in the zebrafish, Brachydanio rerio. Bull Fac Fish Hokkaido Univ 28: $57-65$

Uchida D, Yamashita M, Kitano T, Iguchi T 2002: Oocyte apoptosis during the transition from ovary-like tissue to testes during sex differentiation of juvenile zebrafish. J Exp Biol 205: 711-718

Uchida D, Yamashita M, Kitano T, Iguchi T 2004: An aromatase inhibitor or high water temperature induce oocyte apoptosis and depletion of P450 aromatase activity in the gonads of genetic female zebrafish during sex-reversal. Comp Biochem Physiol A-Mol Integr Physiol 137: 11-20

Zaroogian G, Gardner G, Horowitz DB, Gutjahr-Gobell R, Haebler R, Mills L 2001: Effect of 17ß-estradiol, o,p'-DDT, octylphenol and p,p'-DDE on gonadal development and liver and kidney pathology in juvenile male summer flounder (Paralichthys dentatus). Aquat Toxicol 54: 101-112 